\title{
Evaluation of the Impacts of Land Use and Land Cover Changes Using Erosion Assessment Model at Tikur Wuha Watershed
}

\author{
Tamirneh Kifle, Asnakew Deres, Assefa Birku, Tesfalem Aberham, Demke Mengist
}

\begin{abstract}
Rapid increases in population, forest clearing and continuing search for a farm land have induced pressure on natural resource. In order to reverse such kind of problem assessing the level of problem and finding solution at watershed level is necessary. The studies of land use land cover changes and their effects on soil erosion and runoff patterns at the watershed level are essential in water resource planning and management. This study provides an approach to identify the effects of land use land cover changes on runoff and sediment in Tikur wuha watershed. The changes in land use land cover were associated with growing demand of wood for fire, charcoal, construction materials, household furniture, pulp and paper industries, and expansion of farming and grazing land. The study was conducted the impacts of land use land cover changes, to identify the main cause erosion, to assess soil loss rate in different slope classes, agricultural activities and its effect on land resource by using erosion assessment model. USLE is important to predict the annual soil loss by using different parameters. The necessary data were generated from mean annual rainfall, previous study of the area, erosivity factor, erodibilty factor, topographic factor (LS), the cropping management factor, erosion control factor, both primary and secondary data as well as key informants interview, field observation, by distribution of structural survey questionnaire and field measurement. The result of the analysis showed that the amount of soil loss at Tikur wuha watershed is about 5.58 ton/ ha/yr. The study finding suggest that understanding of some of the socio- economic, institutional and biophysical factors that determine land cover change of the area would contribute to advice appropriate strategies to achieve the desired change in SWC process and to alleviate damage land cover change in the study area. In selecting priority intervention areas in the rehabilitation of land use land cover, strategies should considered the socio-economic and specific land characteristics as well as farmers preference.
\end{abstract}

Keywords: Erosion, USLE, Land Cover, Land Use, SWC and Watershed

DOI: $10.7176 / \mathrm{JNSR} / 10-9-04$

Publication date:May $31^{\text {st }} 2020$

\section{INTRODUCTION}

The LULC pattern of a region is a result of natural and socio economic factors and their utilization by man in time and space. From systems theory thinking and the observed interconnectedness within our natural systems, linking LULC and water resources is imperative (Wei et al, 2007). Land use land cover change (LULCC) can be easily observed in forestry on a global scale, the largest change in terms of land area, and arguably also in terms of hydrologic effects, is from deforestation and a forestation. Deforestation, rapid land use change for farming and overgrazing are likely to affect the hydrologic regime of the rift lakes (Tenalem, 2007).

The amount and peak intensity are two main important characteristics of a rainstorm that influence its potential ability of causing erosion. Volume and peak rate of runoff are measures of runoff erosive (Foster, 1988). Soil erosion by water is also a function of steepness (gradient), slope length, and shape, which modify the energy of the hydrologic inputs. Edibility is the specific property of soil, which can be quantitatively evaluated as the vulnerability of the soil to erosion under specific circumstances (Hudson, 1996). Physical process based models are intended to represent the essential mechanisms controlling erosion process by solving the corresponding equations. These models are the synthesis of individual components that affect the erosion processes and it is argued that they are highly capable to assess both the spatial and temporal variability of the natural erosion processes. The physical based models include AGNPS (Young et al., 1987), ANSWERS (Beasley et al., 1980). Empirical models are like the Universal Soil Loss Equation (USLE) (Wischmeier and Smith, 1965), the Modified Universal Soil Loss Equation (MUSLE) (Williams, 1975) and Agricultural Nonpoint Source Pollution Model (AGNPS) (Young et al., 1987) are examples of commonly used watershed models based on USLE methodology to compute soil erosion. Erosion is a problem at Tikur Wuha water shed Therefore, this study evaluate the impacts of land use and land cover changes

\section{Material and methods \\ Description of the study area}

Tikur wuha watershed located is $266 \mathrm{~km}$ from Addis Ababa, 16k.m from Shashemne in southern direction; $4 \mathrm{~km}$ from Hawassa in northern direction.

Land use and land cover

Most of the watershed area is agricultural land, with rain fed agro forestry practices (mostly perennial and annual cropping). The forests besides supplying the needs of the nation for fuel wood, timber and grazing, served a very 
important purpose of protecting the hill sides against erosion and the valley lands against floods. The bar hill sides flood water during the rain. The result is that the rain water instead of percolating in to the soil runs over the surface of the soil, with great velocity, causing floods, erosion and sedimentation (SCRP, 1995).

The concept of different aspects of effects of land use change on hydrology at local, regional and global scale. Land use change could have an effect on decrease or increase of the quantity of water (Maidment, 1993). Land covers refer to the land surface cover characterized main vegetation type. Thus include crop land forest, wood lands, bush lands and water bodies without reference to how this cover is used. On the other hand, land use refers to the use made of the various land cover types taking in to accounts the type of management linked to economic consideration. In many cases, land cover and land uses are described interrelated.

Climate

Based on the Moisture Index Classification of climate, the climate of the watershed in general is dry sub-humid in the northern part of the high lands and moist sub-humid in the eastern and southern part of the catchment area. Depending on the local climate information the mean annual temperature of the Watershed is about $19.5^{\circ} \mathrm{c}$ and altitude range 1680 to 3000 meters above sea level, the area is predominantly categorized as Woinadega Zone and classified as temperate. The main rainy season in the catchment area is from May to October, but the dry season goes from November to February, similar to the rain pattern of most Ethiopian plateaus. The average annual rainfall estimated to be about $975 \mathrm{~mm}$. The mean monthly temperature varies from $17^{\circ} \mathrm{c}$ to $22^{\circ} \mathrm{c}$. The mean maximum temperature is $30^{\circ} \mathrm{c}$.

\section{Soil classification}

Soils have many physical and chemical characteristics that are useful in describing and differentiating, among them the most important characters include; effective soil depth, soil color, texture, acidity or alkalinity, electrical conductivity, cat ion exchange capacity and base saturation.

\section{Data collection method}

Data availability as well as quality for a watershed can increase the accuracy of model predication.

The data require from this study were collected from both primary and secondary sources.

Primary data: were generated from selected sample house using as structured questionnaire in the watershed face to face interviews in which trained enumerators administer the structured questionnaires, were used to collected primary data.

The data collection were carried out from house hold characteristics, farmer perception of soil erosion, land cover change by interviewing, field observation and by measurements such as land slope ,soil bulk density ,soil depth and soil texture.

House hold characteristics: the necessary data related to the demographic, socioeconomic, agricultural activities related to crop type; cultivation system different investors and institutional factors affecting the land cover changes collected using structured questionnaire through interviewing the house hold.

Field observation: were made to collect on the community and biophysical resources of selected sample house hold within the watershed. In addition through it the land cove change problem, (extent and distribution) and potential opportunities of the area and the status of soil conservation measures, different agricultural practice and currently the land cover in the watershed were observed.

Farmer's perception on soil erosion hazard and land cover change was assessed using formal interviews with sampled households. To obtain information about the same fact from multiple methods and to increase reliability of the data by using group discussion, detailed personal interviews, random sampling technique was used.

A structured questionnaire (appendix-1) was used for the tiled interview and the interview was conducted in the homestead of each interviewed farmer. For the farmer to develop as strong trust on the enumerator, each farmer was well informed about the purpose of the survey and why he /she is chosen for interview, by the Development agents of the kebel. After the formal interview, group discussion has been held in different disciplines such as Agronomy, soil and water conservation experts and natural resources manager in the Woreda of agricultural office and 5 members from farmer, elder people, woman ,kebel of administration and development agents of the study area were held to have the detail information about the attitude of farmers on soil erosion hazard and land cover change and factors that constrain practicing soil and water conservation measures.

Land slope measure: in the study area we were measured the land slope using by leveling instruments and staff rod methods.

\section{Soil bulk density measure}

In the study area we were taken the soil sample in the field. To convert the volume of the soil lost by sheet, rill and gully erosion in to tone/catchments area, the soil bulk density of the study area were investigated. In order to assess and investigate soil bulk density of the study area, total of 6 soil sample were taken from the cultivated land. The samples were taken from up, mid and down position of each of the land. It was investigated by core sampling method.

To find the dry mass weight, the samples were weighed before getting into a $105 \mathrm{c}^{\mathrm{o}}$ oven dry for 24 hours in Hawassa University College of agriculture soil laboratory and weighed after dried. 
The mean of the total samples was taken as the bulk density for the soil on the study area.

Bulk density $\left(\mathrm{gm} / \mathrm{cm}^{3}\right)=\mathrm{Md} / \mathrm{Vt}$

Where, Md mass of dry soil sample (in gram)

VT, total volume of the soil sample (in $\mathrm{cm}^{3}$ )

Secondary data: were collected from which related to biophysical and socio economic features of the watershed was obtained from shasmene Woreda agricultural and rural development office, development agents (DA) as well as published and unpublished documents.

From biophysical data, the status of land use and land cover change, slope type, status of different soil and water conservation measures both physical and biological.

A physical measure includes, level bund, stone bund, area closer and mostly common to apply in the area is soil bund. Biological measures such as, plantation activity, area closer, grass and tree etc...

The farming system of the watershed is characterized as a rain fed subsistence and mixed farming which type of cereal crops such as, maize, teff, sorghum and related cereal crops and livestock productions.

The major livestock type as composition of cattle, sheep, goats, horse, donkey and chickens.

The major trees that are growing on different land use such as Eucalyptus, Acacia and others.

In the study area the land uses type and area in hectares shown in the table below.

\begin{tabular}{lll}
\hline Land use type & Area in(ha) & $\%$ \\
\hline Cultivated land & 650 & 65 \\
Grass land and Forestry & 400 & 35 \\
$\quad$ Total & 1050 & 100 \\
\hline
\end{tabular}

Table-3 land uses type and area

From demographic characteristics such as age, sex, marital status, house hold and family size is shown in the table below.

\begin{tabular}{lll}
\hline House hold & Male & $\mathbf{5 1 1}$ \\
\cline { 2 - 3 } & Female & 119 \\
\multirow{2}{*}{ Family size } & Total & 620 \\
& Male & 1750 \\
& Female & 1303 \\
& Total & 3026 \\
& Total & 3646 \\
\hline
\end{tabular}

Table-4 demographic characteristics

\section{Data analysis}

The data was analyzed using descriptive, quantitative, qualitative and sampling methods.

\section{USLE model description}

The USLE is empirically based model developed in the United States by using data on soil erosion rates (Wischmeier and Smith, 1978).

Mathematically the equation is donated as:

$\mathrm{A}=\mathrm{R} * \mathrm{~K} * \mathrm{~L} * \mathrm{~S} * \mathrm{C} * \mathrm{P}$

Where, $\mathrm{A}$ is the mean annual soil loss (tons/ha/year), $\mathrm{R}$, is the rainfall and runoff factor ( $\mathrm{MJ} \mathrm{mm} / \mathrm{ha} / \mathrm{yr}$ ), $\mathrm{K}$ is the soil erodibility factor (ton $\mathrm{hr} / \mathrm{MJ} \mathrm{mm}$ ), $\mathrm{L}$ is the slope length factor $(-), \mathrm{S}$ is the slope steepness factor $(-)$, C is the land cover and management factor (-) and $\mathrm{P}$, is the support practice factor (-).

\section{Empirical description}

\section{Soil Loss Predicting Model}

The Universal Soil Loss Equation (A model for predicting soil loss)

This equation developed in USA to predict average annual soil loss from interrill and rill erosion. It is given as $\mathrm{A}=\mathrm{RKLSCP}$

Where: - $\mathrm{A}=$ the annual soil loss,

$\mathrm{R}=$ the rainfall erosivity factor,

$\mathrm{K}=$ the soil erodibility factor

$\mathrm{L}=$ the slope length factor

$\mathrm{C}=$ the cropping management factor, and

$\mathrm{P}=$ the erosion control practice factor.

R: The erosivity factor

it can be predicts based on the rain fall data obtained from Hawassa metrological station and adapted for Ethiopian standard condition.

K: The erodibility factor

the erodibility factor can be estimated by filed observation of the soil colour in the watershed. 


\section{Topographic factor, LS factor}

The combination of the length of the slope (L) and the degree of the slope (S) is known as topographic factor (LS factor). LS factor is dimensionless ratio, which allows comparison of the site being estimated with the standard conditions. Can be computed by filed measurement:

Slope length (1);

$\mathrm{L}^{2}=\sum \mathrm{HI}^{2}+\sum \mathrm{VI}^{2}$

Land slope (s);

$\mathrm{S} \%=\frac{\sum \mathrm{VI} * 100}{\sum \mathrm{HI}}$

The cropping management factor, $\mathrm{C}$

The cropping management factor can be computed by formal interview and filed observation method. The erosion control practice factor, $P$

The erosion control practice factor can be computed by formal interview and filed observation method.

\section{Results and Discussion}

\section{Analyses of land use land cover change}

The analysis of land LULC shows that there was significant change in the period between 1965 to 2004 . The result has revealed that using dominant LULC which contributes more than $15 \%$ of the area, the dominant LULC of 1965 were the Dense Wood Land (DSWL), Bushy Wood Land (DBWL), Dense Shrub Land (DSSL) and Wetlands-Non Forested (WETN) changed in to Bare Land (BRLD), Open Bush Land (OPBL), Open Shrub Land (OPSL), and Swampy Grass Land (SWGL) in 2004.

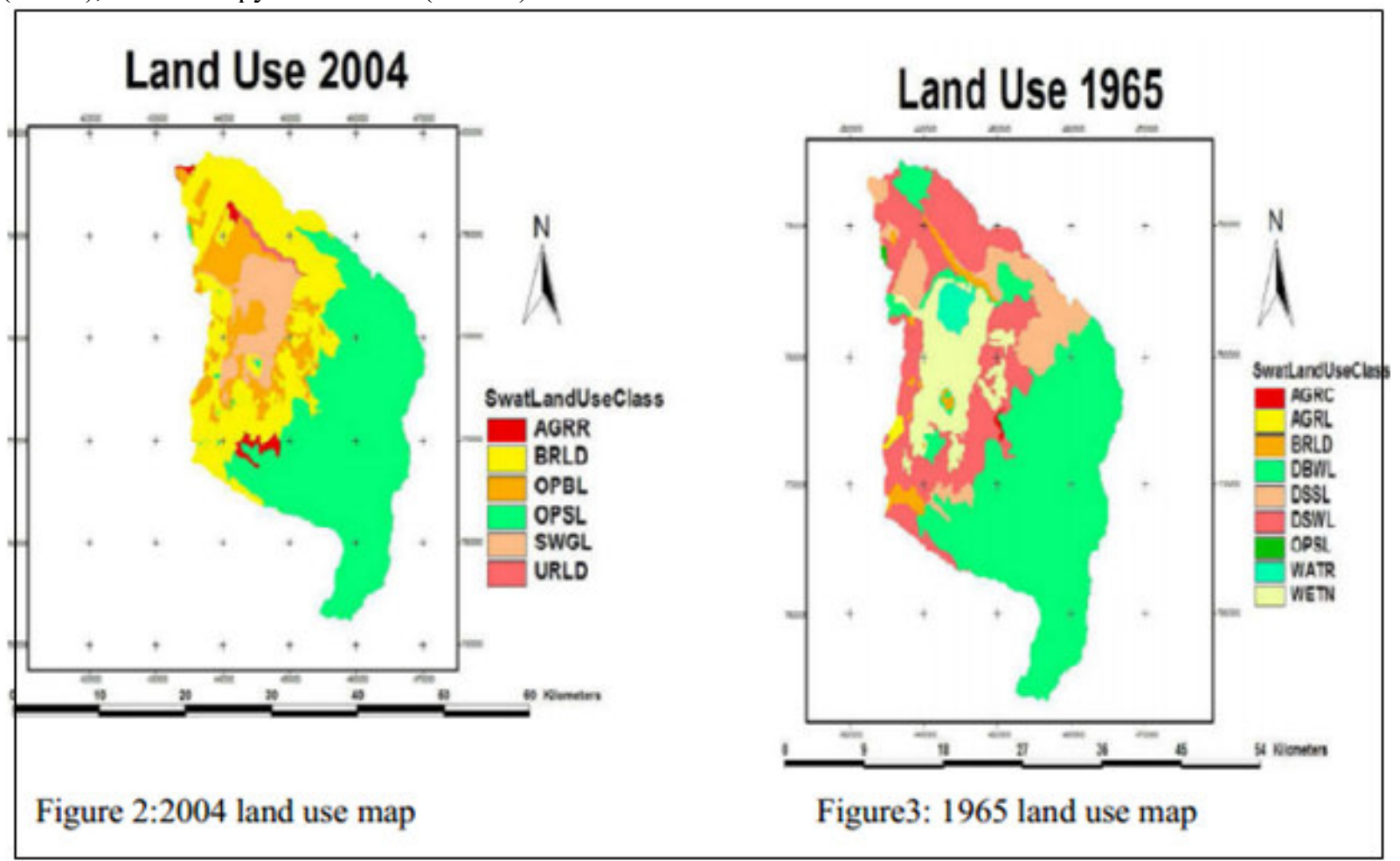

According to (WWDSE, 2004) dens woodland and bush wood land has been changes to open bush land, open grass land and cultivated land. The growing demand of wood for fire, charcoal, construction materials and household furniture's has led to changes.

The evaluation of the land use change shows that most of the woodlands were removed or changed as compared to the situation of the watershed in 1965. The largest part of the bare land is dominated by agricultural and grazing land; with agro forestry practice mainly depend on rain fall. Some private small holding farmers are occupying considerable large portion on the flatter lands. The southern part of Lake Cheleleka, now a swampy area, serves as a very important grazing land. Majority of the rural populations are farmers and their life is based on farming with a considerable income generated from cattle production and cash crops.

The overall change in the study area was dramatic; there were many reasons behind it, and the major ones are during the fall of the Dreg regime the forest cover was invaded by new settlers from different part of the country, these new settlers have created high population pressure so that a need for searching of new farm land became evident (WWDSE, 2001). 
The other factor that contributed to the land use change was that most of the forest area was border of two regional states (Oromo and SNNPR) and there were repeated clashes among the nearby community and incidence of frequent forest fire. And there also limited protection of different illegal timber processing around the area.

\section{Land slope measurement}

Determination of field slope is important in soil and water conservation since erosion is affected by slope of a field. $S \%=\frac{V I}{H I} \times 100$

Were, VI is the vertical interval between the extreme ends of the field.

$\mathrm{HI}$ is the horizontal distance between the extreme ends of the field.

In the study area we use the line level and staff rod method is to measure the land slope.

Line level and staff method

A horizontal line is fixed by the help of a line level and a string of convenient length. The string is tied on staffs. Each staff is placed on each extreme ends. The vertical is determined by two graduated staffs of each one meter in height. The horizontal length of the string is measured using tape meter. The line level is placed on the string of the middle of the staff or rods two persons, called head and rear string men, hold the staffs and one person, called middle string man, hold the line level at the middle and adjust the center. The rear string man holding the staff till the bubble of the line level is centered. The middle string man tells the rear string man to move the string up and down till the line level is correctly leveled.

The difference between the rods reading both staffs gives the vertical interval.

The distance between the two rods gives the horizontal distance.

Based on the above procedures to measure the land slope in the study area was measure the grazing and cultivated land slope.

Grazing land slope in the table shown

\begin{tabular}{|l|l|l|l|l|l|l|}
\hline Land type & $\mathrm{VI}_{1}$ & $\mathrm{VI}_{2}$ & $\mathrm{HI}_{1}$ & $\mathrm{HI}_{2}$ & $\sum \mathrm{VI}$ & $\sum \mathrm{HI}$ \\
\hline Grazing land & $\mathrm{H} 1=1 \mathrm{~m}$ & $\mathrm{H}_{3}=1 \mathrm{~m}$ & $10 \mathrm{~m}$ & $10 \mathrm{~m}$ & $0.75 \mathrm{~m}$ & $20 \mathrm{~m}$ \\
& $\mathrm{H}_{2}=1.35 \mathrm{~m}$ & $\mathrm{H}_{4}=1.4 \mathrm{~m}$ & & & & \\
& $\mathrm{H}_{2}-\mathrm{H}_{1}=0.35 \mathrm{~m}$ & $\mathrm{H}_{4}-\mathrm{H}_{3}=0.4 \mathrm{~m}$ & & & & \\
\hline
\end{tabular}

Table-5 Grazing land slope

Vertical interval is calculated in the above table.

Then to calculating the slope(S), $\quad 11 \mathrm{~m}$ string

Range pole

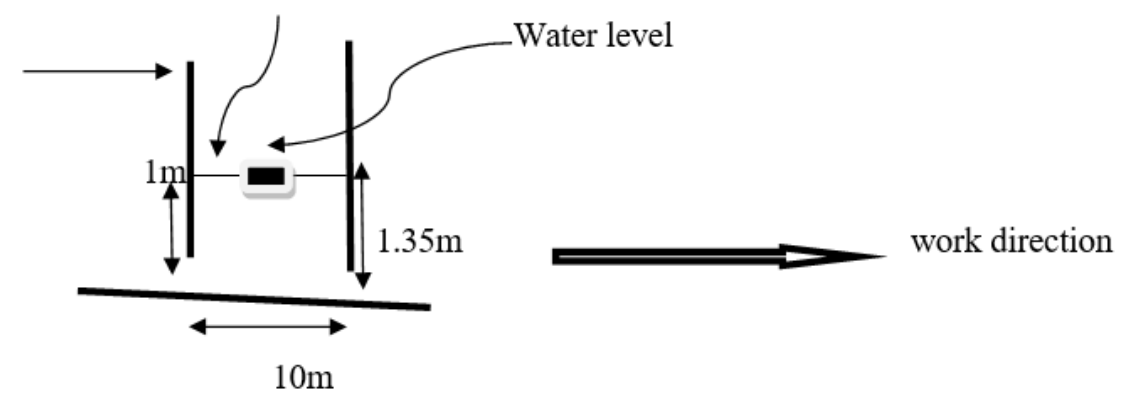

$$
\begin{gathered}
\mathrm{S}_{\%}=\frac{\sum V I}{\sum H I} \times 100 \\
=\frac{0.75 \times 100}{20}
\end{gathered}
$$

$$
\mathrm{S} \%=3.75
$$

The slope ranges between $2-5 \%$ is gentle slope. The calculated slope is between the ranges.

Calculating the Slope length (L)

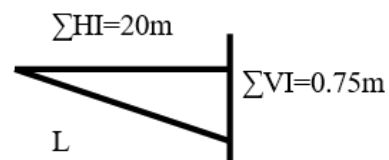

$$
\begin{gathered}
\left(\mathrm{L}^{2}\right)=\left(\sum \mathrm{VI}\right)^{2}+\left(\sum \mathrm{HI}\right)^{2} \\
=(0.35+0.4)^{2}+(10+10) 2 \\
\mathrm{~L}^{2}=0.75^{2}+20^{2} \\
\mathrm{~L}=20.014
\end{gathered}
$$


Cultivated land slope in the table below shown

\begin{tabular}{|l|l|l|l|l|l|l|}
\hline Land type & $\mathrm{VI}_{1}$ & $\mathrm{VI}_{2}$ & $\mathrm{VI}_{3}$ & $\mathrm{VI}_{4}$ & $\mathrm{VI}_{5}$ & $\sum \mathrm{VI}$ \\
\hline & $\mathrm{H}_{1}=1 \mathrm{~m}$ & $\mathrm{H}_{3}=1 \mathrm{~m}$ & $\mathrm{H}_{5}=1 \mathrm{~m}$ & $\mathrm{H}_{7}=1 \mathrm{~m}$ & $\mathrm{H}_{9}=1 \mathrm{~m}$ & $2.61 \mathrm{~m}$ \\
& $\mathrm{H}_{2}=1.58 \mathrm{~m}$ & $\mathrm{H}_{4}=1.55 \mathrm{~m}$ & $\mathrm{H}_{6}=1.5 \mathrm{~m}$ & $\mathrm{H}_{8}=1.56 \mathrm{~m}$ & $\mathrm{H}_{10}=1.43 \mathrm{~m}$ & \\
& $\mathrm{H}_{2-} \mathrm{H}_{1}$ & $\mathrm{H}_{4-} \mathrm{H}_{3}$ & $\mathrm{H}_{6-} \mathrm{H}_{5}$ & $\mathrm{H}_{8}-\mathrm{H}_{7}$ & $\mathrm{H}_{10}-\mathrm{H}_{9}$ & \\
& $=1.58 \mathrm{~m}-1 \mathrm{~m}$ & $=1.55 \mathrm{~m}-1 \mathrm{~m}$ & $=1.5 \mathrm{~m}-1 \mathrm{~m}$ & $=1.56 \mathrm{~m}-1 \mathrm{~m}$ & $=1.43 \mathrm{~m}-1 \mathrm{~m}$ & \\
& $=0.58 \mathrm{~m}$ & $=0.55 \mathrm{~m}$ & $=0.5 \mathrm{~m}$ & $=0.56 \mathrm{~m}$ & $=0.43 \mathrm{~m}$ & \\
\cline { 2 - 7 } Cultivated land & $\mathrm{HI}_{1}$ & $\mathrm{HI}_{2}$ & $\mathrm{HI}_{3}$ & $\mathrm{HI}_{4}$ & $\mathrm{HI}_{5}$ & $\sum \mathrm{HI}$ \\
& $=10 \mathrm{~m}$ & $=10 \mathrm{~m}$ & $=10 \mathrm{~m}$ & $10 \mathrm{~m}$ & $10 \mathrm{~m}$ & $50 \mathrm{~m}$ \\
\hline
\end{tabular}

Table-6 Cultivated land slope

Where, VI is vertical interval

$\mathrm{HI}$ is horizontal distance

The total vertical interval is,

$$
\begin{gathered}
\sum \mathrm{VI}=\mathrm{VI}_{1}+\mathrm{VI}_{2}+\mathrm{VI}_{3}+\mathrm{VI}_{4}+\mathrm{VI}_{5} \\
=0.58 \mathrm{~m}+0.55 \mathrm{~m}+0.5 \mathrm{~m}+0.56 \mathrm{~m}+0.43 \mathrm{~m} \\
=2.61 \mathrm{~m}
\end{gathered}
$$

The total horizontal distance is, $\sum H I=\mathrm{HI}_{1}+\mathrm{HI}_{2}+\mathrm{HI}_{3}+\mathrm{HI}_{4}+\mathrm{HI}_{5}$ $=10 \mathrm{~m}+10 \mathrm{~m}+10 \mathrm{~m}+10 \mathrm{~m}+10 \mathrm{~m} \quad=50 \mathrm{~m}$

Then to calculate the slope
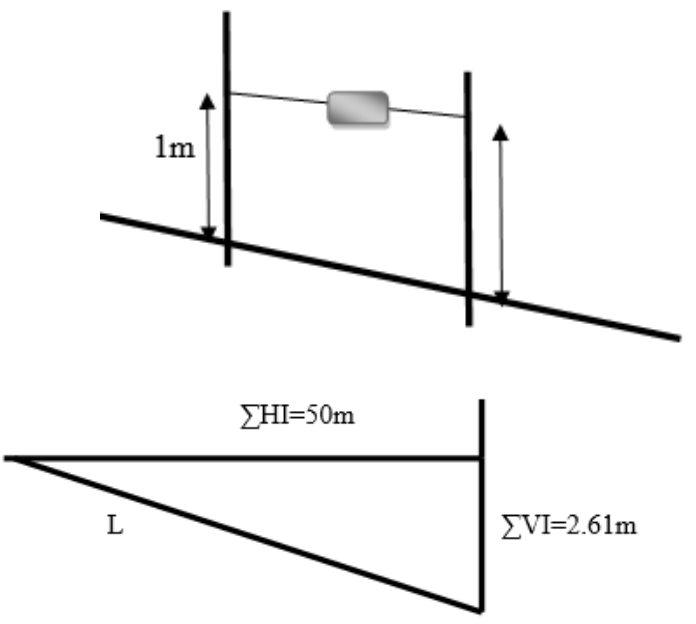

The slope range between $5-10 \%$ is rolling.

The calculated slope is between these ranges.

Slope length (L)

$$
\begin{aligned}
\mathrm{S} \% & =\frac{\sum \mathrm{VI}}{\sum H I} \times 100 \\
\mathrm{~S} \% & =\frac{2.61 \times 100}{50} \\
& =5.22
\end{aligned}
$$

To determine the soil BULK density,

$$
\begin{gathered}
\mathrm{L}^{2}=\left(\sum \mathrm{VI}\right)^{2}+\left(\sum \mathrm{HI}\right)^{2} \\
=(26.1 \mathrm{~m})^{2}+(50 \mathrm{~m})^{2} \\
\mathrm{~L}=50.068 \mathrm{~m}
\end{gathered}
$$

\begin{tabular}{llllllll}
\hline $\begin{array}{l}\text { Sample } \\
\text { No }\end{array}$ & $\begin{array}{l}\text { Saturated } \\
\text { mass(gm) }\end{array}$ & $\begin{array}{l}\text { Oven dry } \\
\text { mass(gm) }\end{array}$ & $\begin{array}{l}\text { Mass of core } \\
\text { sampler(gm) }\end{array}$ & $\begin{array}{l}\text { Mass of } \\
\text { dry soil } \\
(\mathrm{gm})\end{array}$ & $\begin{array}{l}\text { Bulk } \\
\text { volume }\left(\mathrm{cm}^{3}\right)\end{array}$ & $\begin{array}{l}\text { Volume of } \\
\text { water } \\
\text { evaporated }\end{array}$ & $\begin{array}{l}\text { Bulk } \\
\text { density }\left(\boldsymbol{\rho}_{\mathrm{b}}\right) \\
\left(\mathrm{gm} / \mathrm{cm}^{3}\right)\end{array}$ \\
\hline 1 & 262.4 & 238 & 97.6 & 140.4 & 98.17 & 24.4 & 1.43 \\
2 & 263 & 236.9 & 97.6 & 139.3 & 98.17 & 26.1 & 1.42 \\
3 & 257.2 & 241.8 & 97.6 & 144.2 & 98.17 & 15.4 & 1.47 \\
4 & 273.7 & 238.8 & 97.6 & 141.2 & 98.17 & 34.9 & 1.44 \\
5 & 268.2 & 245 & 97.6 & 147.4 & 98.17 & 23.2 & 1.50 \\
6 & 264.2 & 235.9 & 97.6 & 138.3 & 98.17 & 28.3 & 1.41 \\
& & Average & 141.8 & 98.17 & 25.4 & 1.45 \\
\hline
\end{tabular}

Calculation:

\section{Given}

Core sampler diameter $(\mathrm{D})=5 \mathrm{~cm}$

$\mathrm{R}=\frac{1 D}{2}=2.5 \mathrm{~cm}$

Length $(\mathrm{Lc})=5 \mathrm{~cm}$

Mass of core sampler $(\mathrm{MC})=97.6 \mathrm{gm}$

$\rho_{\mathrm{w}}=1 \mathrm{gm} / \mathrm{cm}^{3}$ at $20 \mathrm{c}^{\circ}$

Calculation to fill the above table

\section{$\underline{\text { Required }}$}

Soil bulk density $\left(\rho_{\mathrm{b}}\right)$ ? 
For sample No 1 we have volume of core sampler=bulk volume (total volume)

$\mathrm{VC}=\mathrm{Ac} * \mathrm{Lc}$

Where, AC is area of core sampler it has cylindrical shape

And LC, is the length of core sampler

From the above table to find the mass of water $(\mathrm{Mw})$ :

$$
\begin{gathered}
\text { Then } \mathrm{AC}=\pi \mathrm{Dc}^{2} / 4 \\
=\pi(5 \mathrm{~cm})^{2} / 4 \\
=19.625 \mathrm{~cm}^{2}
\end{gathered}
$$

$\mathrm{Mw}=$ sat-mass - oven dry mass

$\mathrm{Mw}=262.4 \mathrm{gm}-238 \mathrm{gm}=24.4 \mathrm{gm}$

The mass of dry soil (Md):

$$
\mathrm{Md}=\text { oven dry mass }- \text { mass of core sampler }(\mathrm{Mc})
$$

$$
\begin{aligned}
\mathrm{Md} & =238 \mathrm{gm}-97.6 \mathrm{gm} \\
& =140.4 \mathrm{gm}
\end{aligned}
$$

Using the above information we can determine the bulk density of the soil:

$$
\begin{gathered}
\rho_{\mathrm{b} 1}=\text { mass of dry soil }(1) / \text { Vtotal } \\
\rho_{\mathrm{bl}}=\mathrm{Md} 1 / \mathrm{VT} \\
=140.4 \mathrm{gm} / 98.17 \mathrm{~cm}^{3} \\
=1.43 \mathrm{gm} / \mathrm{cm}^{3}
\end{gathered}
$$

Repeat the above calculation for sample (6) and the soil sample with the same calculation:

We are given for sample (6)

$\mathrm{VT}=98.17 \mathrm{~cm} 3$

$$
\begin{gathered}
\mathrm{Mw} 6=\text { sat- mass } 6-\text { oven dry mass } 6 \\
=264.2 \mathrm{gm}-235.9 \mathrm{gm} \\
=28.3 \mathrm{gm}
\end{gathered}
$$

The mass of dry soil (Md6):

$$
\begin{gathered}
\text { Md 6= oven dry mass6 }- \text { mass of core sampler }(\mathrm{Mc}) \\
=235.9 \mathrm{gm}-97.6 \mathrm{gm} \\
=138.3 \mathrm{gm}
\end{gathered}
$$

Then to determine the bulk density of sample (6):

$$
\rho_{\mathrm{b} 6}=\mathrm{Md} 6 / \mathrm{VT}=138.3 \mathrm{gm} / 98.17 \mathrm{~cm} 3=1.41 \mathrm{gm} / \mathrm{cm}^{3}
$$

\section{Texture analysis}

Texture, or size distribution of mineral particles (or its associated pore volume), is one of the most important measures of a soil because finely divided soil particles have much greater surface area per unit mass or volume than do coarse particles. Soil (mineral) particles are broadly segregated into three size classes (1) sand - individual particles visible with the naked eye, (2) silt - visible with a light-microscope, and (3) clay - some may not be visible with a light-microscope, especially the colloidal size (i.e., $<1$ micrometer or 0.001 millimeter).This sand, silt and clay groups are commonly referred to as the soil separates; soil texture is defined as the relative proportions of each class. In the study area the soil type is sandy (by bulk density). The soil texture of the study area was determined in the ACA campus school of horticultural and plant science soil laboratory by using hydrometer method.

\section{Materials}

1. Sieved soil (50 g dry wt. sandy).

2. Electric mixer and cup.

3. Sedimentation cylinder $(1000 \mathrm{~mL})$.

4. Hydrometer

5. Thermometer $\left(23^{\circ} \mathrm{C}\right)$.

Reagents , Hydrogen per oxide

\section{Procedure}

1. Place $50 \mathrm{~g}$ of soil (dry weight) into a soil dispersing cup.

2. Fill cup to within two inches of the cup with distilled water, should be at room temperature.

3. Add $5 \mathrm{ml}$ of hydrogen per oxide.

4. Allow to slake (soak) for 5 minutes sandy soils

5. Transfer suspension to sedimentation cylinder; use distilled water from squirt bottle to get all of sample from mixing cup

6. Fill cylinder to $1000-\mathrm{mL}$ mark with distilled water.

7. Carefully mix suspension with plunger. After removing plunger, begin timing. Carefully place 
hydrometer into suspension; note reading at 40 seconds. Read the hydrometer at the top of the meniscus rather than at the bottom.

8. After final 40-second reading, remove hydrometer, carefully lower a thermometer into the suspension and record the temperature $\left({ }^{\circ} \mathrm{C}\right)$. Record the temperature for both hydrometer readings (40 sec and $2 \mathrm{hr}$.)

9. Mix suspension again and begin timing for the two-hour reading

10. Make up a blank cylinder with water and hydrogen per oxide. Record the blank hydrometer reading

11. Take a hydrometer reading at 2 hours, followed by a temperature reading.

\section{Calculations}

1. Temperature correction factor, $\mathrm{T}$ (may be different for each reading):

2. Corrected 40-second reading: $40-\sec (\mathrm{c})$

$$
\mathrm{T}=\left(\text { Observed temperature }-23^{\circ} \mathrm{C}\right) * 0.3=6.9
$$

3. Corrected 2-hour reading: 2-hr(c)

$$
\begin{gathered}
=40-\text { sec }- \text { Blank }+\mathrm{T} \\
=29+6.9=35.9
\end{gathered}
$$

$$
\begin{gathered}
=2-\mathrm{hr}-\text { Blank }+\mathrm{T} \\
=10+6.9=16.9
\end{gathered}
$$

4. \%of sand $(2-0.05 \mathrm{~mm})$

$$
\begin{gathered}
=\frac{(\text { OD soil wt })-(\text { corr- } 40-\text { second reading }) * 100}{\text { OD soil wt }} \\
=\frac{50 \mathrm{gm}-35.9 \mathrm{gm}}{50 \mathrm{gm}} * 100 \% \\
=28.2 \%
\end{gathered}
$$

5. $\% \operatorname{clay}(<0.002 \mathrm{~mm})$

6. $\%$ Silt $(0.05-0.002 \mathrm{~mm})$

$$
\begin{aligned}
= & \frac{\text { corr. } .2 \text { hr reading }}{O D \text { soil wt }} * 100 \% \\
& =33.8 \%
\end{aligned}
$$

$$
\begin{gathered}
=100 \%-(\% \text { sand }+\% \text { clay }) \\
=100 \%-(28.2 \%+33.8 \%) \\
=100 \%-62 \% \\
=38 \%
\end{gathered}
$$

According to the percentage of soil triangle the soil textural class is clay loam.

\begin{tabular}{ll}
\hline Class of soil depth & Range $(\mathrm{cm})$ \\
\hline Deep & $>90$ \\
Moderately & $50-90$ \\
Shallow & $20-50$ \\
Very shallow & $<20$ \\
\hline \multicolumn{2}{c}{ Table -8 Soil depth }
\end{tabular}

The soil depth of the study area measuring by tape meter from top soil to bottom layers of the soil.

Depth $(\mathrm{D} 1)=0.35 \mathrm{~m}, \quad$ Depth $(\mathrm{D} 2)=0.5 \mathrm{~m}$, Depth $(\mathrm{D} 3)=0.25 \mathrm{~m}$, Depth $(\mathrm{D} 4)=0.3 \mathrm{~m}$

Then to calculate the average soil depth,

$$
\text { Dav }=\frac{0.35 m+0.5 m+0.25 m+0.35 m}{4}
$$

The study area of the soil depth ranges between $20-50 \mathrm{~cm}$ and the class of soil depth is shallow.

The rain fall data for the study area obtained from Hawassa metrological station from (2003-2012) in (appendix2)

The annual rain fall is shown in the table below

\begin{tabular}{ll}
\hline Year & Annual rain fall in $(\mathrm{mm})$ \\
\hline 2003 & 821.4 \\
2004 & 825.6 \\
2005 & 997.6 \\
2006 & 1188.9 \\
2007 & 1167.5 \\
2008 & 915.4 \\
2009 & 704.3 \\
2010 & 1038.8 \\
2011 & 902.8 \\
2012 & 785.4 \\
\hline
\end{tabular}

Table -9 annual rain fall 
In the above table the annual rain fall in 2012 is 785.4 . Then to calculate the rain fall factor(R) based on the adapted Ethiopian condition of the annual rain fall and rain fall factor.

Use interpolation method to calculate the rain fall factor $(\mathrm{R})$,

$\mathbf{K}($ the soil erodibility)

\begin{tabular}{ll}
\hline Annual rain fall $(\mathrm{mm})$ & Rain fall factor $(\mathrm{R})$ \\
\hline 400 & 217 \\
785.4 & $\mathrm{R}$ \\
800 & 441 \\
\hline
\end{tabular}

$$
\begin{gathered}
\text { Table }-10 \text { rainfall factor } \\
=\frac{400-785.4}{785.4-800}=\frac{217-R}{R-441} \\
\frac{385.4}{14.6}=\frac{217-R}{R-441} \\
385.4(\mathrm{R}-441)=14.6(217-\mathrm{R}) \\
385.4 \mathrm{R}-169961.4=3168.2-14.6 \mathrm{R} \\
385.4 \mathrm{R}+14.6 \mathrm{R}=173129.6 \\
400 \mathrm{R}=173129.6 \\
\mathrm{R}=432.824
\end{gathered}
$$

This factor is prepared to be estimated based on the soil color. The soil color is brown then $\mathrm{K}$ value is 0.2

L:slope length of the study area we take the cultivated land slope

Using Pythagoras theorem

$$
\begin{gathered}
\mathrm{L}^{2}=\sum \mathrm{HI}^{2}+\sum \mathrm{VI}^{2} \\
\mathrm{~L}^{2}=50^{2}+2.61^{2} \\
\mathrm{~L}^{2}=2506.8121 \\
\mathrm{~L}=\sqrt{2506.8121} \\
\mathrm{~L}=50.068 \mathrm{~m}
\end{gathered}
$$

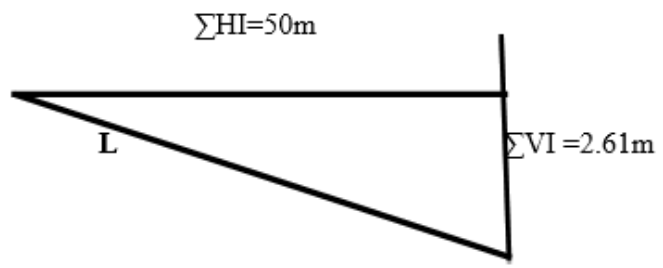

The calculated slope length occurs between 40 and 80 slope length of Ethiopian conditions. By using interpolation to calculate the slope length factor $(\mathrm{L})$.

\begin{tabular}{ll}
\hline Slope length $(\mathrm{m})$ & Length factor $(\mathrm{L})$ \\
\hline 40 & 1.4 \\
50.068 & $\mathrm{~L}$ \\
80 & 1.9 \\
\hline
\end{tabular}

Table -11 slope length factor

Using interpolation method

$$
\begin{gathered}
\frac{40-50.068}{50.068-80}=\frac{1.4-L}{L-1.9} \mathrm{~S} \\
\frac{10.068}{29.932}=\frac{1.4-L}{L-1.9} \\
10.068(\mathrm{~L}-1.9)=29.932(1.4-\mathrm{L}) \\
10.068 \mathrm{~L}-10.068 * 1.9=29.932 * 1.4-29.932 \mathrm{~L} \\
10.068 \mathrm{~L}+29.932 \mathrm{~L}=10.068 * 1.9+29.932 * 1.4 \\
40 \mathrm{~L}=61.034 \\
\mathrm{~L}=\frac{61.034}{40} \\
\mathrm{~L}=1.5
\end{gathered}
$$

S:slope gradient

The slope of the cultivated land of the study area can be calculated as follows.

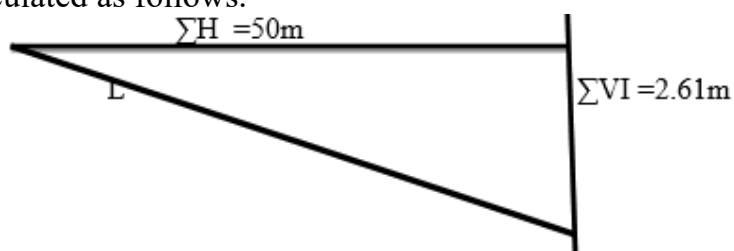

$$
\mathrm{S} \%=\frac{\sum V I * 100}{\sum H I}
$$




$$
\begin{array}{r}
\mathrm{S} \%=\frac{2.61 * 100}{50} \\
\mathrm{~S} \%=5.22
\end{array}
$$

The calculated slope gradient occurs between 5 and 10\% of slope gradient of Ethiopian conditions.

By using interpolation the slope gradient can be calculated as follows.

\begin{tabular}{ll}
\hline Slope gradient(S \%) & Gradient factor(s) \\
\hline $\mathrm{S}$ & 0.4 \\
5.22 & $\mathrm{~S}$ \\
10 & 1.0 \\
\hline
\end{tabular}

Table -12 Slope gradient factor

$$
\begin{aligned}
& \frac{5-5.22}{5.22-10}=\frac{0.4-S}{S-1} \\
& \frac{0.12}{4.78}=\frac{0.4-S}{S-1} \\
& 0.22(\mathrm{~S}-1)=4.78(0.4-\mathrm{S}) \\
& 0.22 \mathrm{~S}-0.22=4.78 * 0.4-4.78 * \mathrm{~S} \\
& 5 \mathrm{~S}=2.132 \\
& \mathrm{~S}=0.43
\end{aligned}
$$

$>$ C: the land cover of the study area commonly sorghum and maize. Then the $\mathrm{C}$ value is 0.1

$>$ P: management factor

Management practice commonly in the farms ploughing up and down then the $\mathrm{P}$ value is 1.00

Based on the above information, to calculate the annual soil loss by using

USLE equation method in cultivated land

A= Annual soil loss (ton/ha/yr.)

$$
A=R * K * L * S * C * P
$$

$\mathrm{R}=$ Erosivity factor $(\mathrm{R}=432.824)$

$\mathrm{K}=$ Erodibility factor $(\mathrm{K}=0.2)$

$\mathrm{L}=$ Slope length factor $(\mathrm{L}=1.5)$

$\mathrm{S}=$ Slope gradient factor $(\mathrm{S}=0.43)$

$\mathrm{C}=$ Land cover factor $(\mathrm{C}=0.1)$

$\mathrm{P}=$ Management factor $(\mathrm{P}=1.0)$

Then the annual soil loss (A)

$$
\begin{gathered}
\mathrm{A}=432.824 * 0.2 * 1.5 * 0.43 * 0.1 * 1.0 \\
=5.58 \text { ton } / \mathrm{ha} / \mathrm{yr} .
\end{gathered}
$$

Accordingly the degree of soil erosion or loss can be expressed as weak; medium; serious; severe and Very severe erosion.

\begin{tabular}{ll}
\hline $\begin{array}{l}\text { Erosion intensity } \\
\text { (ton/ha/yr) }\end{array}$ & Verbal assessment \\
\hline $0.5-5$ & Weak erosion \\
$5-15$ & medium erosion \\
$15-50$ & serious erosion \\
$50-200$ & severe erosion \\
$>2000$ & Very severe erosion \\
\hline
\end{tabular}

Source: (plesnik 1958)

Weak erosion: - causing annual soil loss from $0.05-0.5 \mathrm{~mm}$ depth or from $0.5-5$ ton $/ \mathrm{ha} / \mathrm{yr}$.

$>$ Medium erosion: - it causes annual soil loss ranging from $0.5-1.5 \mathrm{~mm}$ of soil depth or from $5-15 \mathrm{ton} / \mathrm{ha} / \mathrm{yr}$.

$>$ Serious erosion: - it indicates great danger to the soil because top or upper fertile soil is removed in this erosion. The range of soil loss in this erosion varies from $1.5-5 \mathrm{mmof}$ soil depth or from $15-50$ ton/ha/yr.

$>$ Severe erosion:-it is a case of extreme soil erosion; in which extreme danger to soil takes place. The range of annual soil loss varies from 5-20mm of soil depth or from 50 -200 ton/ha/yr.

$>$ Very severe erosion: - in this erosion; the erosion intensity is much greater; as result there is greater consequence than the severe erosion. The average soil removal is found more than $2000 \mathrm{ton} / \mathrm{ha} / \mathrm{yr}$.

According to the degree of soil erosion in the study area the annual soil loss is $5.58 \mathrm{ton} / \mathrm{ha} / \mathrm{yr}$. Then the degree of soil erosion is medium.

\section{Sediment yield}

The amount of eroded materials which completes the journey from origin point to the downstream control point such as reservoir is called sediment yield. The sediment yield from watershed is always less than gross soil erosion. The ratio of amount of sediment yield to the gross erosion is called sediment delivery ratio (SDR). 
$\mathrm{SDR}=\frac{\text { sediment yield }}{\text { gross erosion }}$

The SDR is expressed as the percent of sediment yield to gross erosion. The value of SDR is less than 1, because sediment yield is less in magnitude than the gross erosion. The measurements show that, as little as $5 \%$ and as much as $100 \%$ of materials eroded in some watersheds can be delivered to a downstream point. In the above annual soil loss of the watershed is $5.58 \mathrm{ton} / \mathrm{ha} / \mathrm{yr}$. Let assume the SDR value is $(35 \%, 65 \%$ and $95 \%)$ and can be estimated the sediment yield of the watershed.

For SDR $=35 \%$,

$$
\begin{aligned}
\text { Sediment yield }= & \text { SDR } * \text { Gross erosion (annual soil loss) } \\
= & 35 \% * 5.58 \text { ton } / \mathrm{ha} / \mathrm{yr} \\
& =1.95 \text { ton } / \mathrm{ha} / \mathrm{yr}
\end{aligned}
$$

For $\mathrm{SDR}=65 \%$,

$$
\begin{gathered}
\text { Sediment yield }=65 \% * 5.58 \mathrm{ton} / \mathrm{ha} / \mathrm{yr} \\
=3.62 \mathrm{ton} / \mathrm{ha} / \mathrm{yr}
\end{gathered}
$$

For $\mathrm{SDR}=95 \%$,

$$
\begin{gathered}
\text { Sediment yield }=95 \% * 5.58 \mathrm{ton} / \mathrm{ha} / \mathrm{yr} \\
=5.3 \mathrm{ton} / \mathrm{ha} / \mathrm{yr}
\end{gathered}
$$

Then the average sediment yield in the watershed is,

$$
\begin{aligned}
& =\frac{1.95+3.62+5.3}{3} \\
& =3.62 \mathrm{ton} / \mathrm{ha} / \mathrm{yr}
\end{aligned}
$$

Farmer's perception of land use and land cover change and soil erosion hazards

The result from farmer's focus group discussion and key informer's interviews should that farmers are well aware of what land cover change is, were able to identify the causes, indicators and impacts. Participant's perceived land cover change as the removal of forest, loss of soil and water recourses in the watershed. The main cause's suggested by farmers were population pressure, deforestation, rapid expansion of urbanization and the land occupied by investors. The investors have positive and negative impacts of land use and land cover.

The positive impacts of the investors

$\checkmark \quad$ To create the job for the people around the area

$\checkmark$ To reduce independent of the others

$\checkmark \quad$ To reduce poverty

$\checkmark \quad$ To developed the economy etc.

The negative impacts of the investors

$\checkmark$ To reduce land cover change

$\checkmark$ To facilitate soil erosion

$\checkmark$ Poor management of SWC measures of the area etc.

The participants also identify that major impacts as loss of soil fertility, decreasing production, depletion of water recourse, flooding and siltation.

The table below shows the degree of erosion problem

\begin{tabular}{ll}
\hline Degree of erosion & No of farmers \\
\hline Low & 1 \\
Medium & 3 \\
High & 5 \\
\hline
\end{tabular}

Table -14 degree of soil erosion

The rank of major causes of soil erosion in the area

\begin{tabular}{llll}
\hline No & Causes of soil erosion & No of farmers & Rank \\
\hline 1 & Deforestation & 6 & 1 \\
2 & Overgrazing & 4 & 2 \\
3 & Over cultivation & 3 & 3 \\
4 & Poor agricultural practices & 1 & 5 \\
5 & Excess rain fall & 0 & 6 \\
6 & Poor governmental management & 2 & 4 \\
\hline
\end{tabular}

Table -15 the rank of major causes of soil erosion

The Woreda agricultural experts and development agent's perception for the cause of soil erosion and land cover changes

Before 20 years the land was covered by green area or natural forests. From year to year the land cover rapidly decreases by different causes, such as population growth, deforestation, expansion of urbanization construction and road construction. Due to the removal of the land cover results initiation of soil erosion. The major causes of soil erosion, deforestation, over grazing, cultivation, poor agricultural practice, lack of knowledge of SWC 
measures etc. the effects of soil erosion such as loss of soil fertility, decreasing production, increasing poverty and climate change.

\section{Conclusion and recommendation}

Land use land cover is a term that includes categories of land use and land cover. Land cover is the physical or other kind of material that covers of the land surface. Land use is the purpose of human activity on the land. Land use land cover change can be easily observed in forestry on global scale, the largest change in terms of land area, and arguably also in terms of hydraulic effects, is from deforestation, rapid land use change for poor farming activity are, overgrazing and lack of SWC awareness. Changes in land use from 1965 to 2004 land use pattern at Tikurwuha catchment have caused a higher sediment yield. From this study, it can be conclude that there were drastic land use land cover change between 1965 and 2004 due to land use competition between cultivated land and wood land, grazing land and lives toke production, fuel wood collection and wood land regeneration etc. The increasing need for fuel wood charcoal, construction pole and the expansion of cultivated land adversely affect the natural vegetation cover. The rapid expansion of farm lands, deforestation and high population growth in the area resulted in high rate of soil erosion in the catchment area. The high soil loss rate in the catchment can be attributed to the deforested lands, the poor land cover, the shallow soil depth, and high rain fall intensity. Moreover the cultivated areas have the highest soil loss rate, followed by grass land, shrub land, urban area and forest respectively.

To maximize the available resources integrating the effect of soil erosion in soil loss, those land uses and slope classes having high rate of erosion should be given first priority during the introduction of intensive and well-designed SWC interventions at Tikurwuha watershed. From the research we recommend that the water shed will be plan to develop biological and physical soil conservation measures.

\section{References}

Admassu, D. and Casselman J. (2000). Otolith age determination for adult tilapia, Oreochromisniloticus L. from Lake Hawassa (Ethiopian Rift Valley) by interpreting biannual and differentiating biannualrecruitment. Hydrobiologia; 418:15-24.

Beasle D.B Huggins L.F and Monke E.J. (1980). ANSWERS: a model for water shade planning Trans ASAE; 23(4): 938-944.

Food and Agricultural Organization (FAO), (1984). Ethiopian highlands reclamation study (EHRS). Final Report Rome: $1-2$.

Foster, G. R. (1988). Modeling soil erosion and sediment yield, (Lal, R. (Ed.), Soil erosion research methods, Soil and Water Conservation Society.

Hurni, H. (1988).Degradation and conservation of the resources in the Ethiopian high lands.Mountain Research and Development; 8:2-3.

Hudson, N. (1996).Soil conservation (Second edition) London: B.T. Bats ford. Lal and

Morgan RPC. (2001). a simple approach to soil loss prediction: a revised Morgan-Morgan-Finney model. Catena; 44: $305-322$.

Tenalem Ayenew. (2007): Some Improper Water Resources Utilization Practices and Environmental Problems in the Ethiopian Rift. Africa water journal; 1 (1):80-105.

Wei, W., Chen, L., Fu, B., Huang, Z., Wu, D and Gui, L, (2007). The effect of land uses and rain fall regimes on runoff and soil erosion in the semi-arid loess hilly area, China. Journal of Hydrology 335, 247-258.

Williams, J.R. (1975). Sediment yield prediction with universal equation using run off energy factor. In Present and prospective technology for predicting sediment yield and sources: Proceedings of the sediment yield workshop, USDA

Wischmeier W.H., Smith DD. (1965). Predicting rainfall-erosion losses from crop land east of Rocky Mountains: guide for selection of practices for soil and water conservation. US department of agriculture, Agricultural hand book 282

Young RA.Onstad CA, Bosch DD. Anderson WP. (1987). AGNPS: an agricultural point source pollution model. Conservation research report 35, US Dept. Agric. Res.Services, Washington, DC, USA.

Yemane G. (2004).Assessment of Water Balance of Lake Hawassa Catchment, MSc ITCEnschede, the Netherlands 